\title{
Enhanced Anti-cancer Efficacy in MCF-7 Breast Cancer Cells by Combined Drugs of Metformin and Sodium Salicylate
}

\author{
Yun-Ji Kim ${ }^{1}$, Hee-Bin Park ${ }^{1}$, Pyung-Hwan Kim ${ }^{1}$, James S. Park ${ }^{2}$ and Keun-Sik Kim ${ }^{1, \uparrow}$ \\ ${ }^{I}$ Department of Biomedical Laboratory Science, Konyang University, Daejeon 35365, Korea \\ ${ }^{2}$ Department of Medicine, New York University School of Medicine, New York, NY 10016, USA
}

\begin{abstract}
Metformin or sodium salicylate is known to induce apoptosis and G0/G1 phase arrest in a variety of cancer cells. However, the anti-cancer effects of the combined treatments for these drugs-induced apoptosis are yet unclear. Here, we found that the combined treatment of metformin and sodium salicylate increased the efficacy of chemotherapeutics against breast cancer cells. These combined drugs significantly inhibited cellular proliferation and induced apoptosis at an earlier stage in human MCF-7 breast cancer cells. Also, co-treatments of metformin and sodium salicylate induced G1 cell cycle arrest in MCF-7 cells more effectively than either agent alone. Taken together, these results demonstrate that dual metformin/ sodium salicylate treatment prevents proliferation of MCF-7 cells by inducing apoptosis and G1 cell cycle arrest.
\end{abstract}

Key Words: Breast cancer cell, Combination treatment, Metformin, Sodium salicylate

Breast cancer is the most common cause of cancer death in women worldwide (Mandy et al., 2012). The treatment approach in breast cancer, with antitumor agents in combination chemotherapy, is used routinely due to widespread evidence that multi-chemotherapy offers a survival advantage compared with single-drug therapy (Aapro, 2001; Hu et al., 2012). Thus, it is important to provide evidence of the effectiveness of new combined drugs for the control of proliferation, invasive and metastatic capacity of breast cancer (Conforti and Menichini, 2011). Currently, metformin is an oral antihyperglycemic drug applied for treatment of type 2 diabetes. Recent studies have demonstrated that metformin inhibits proliferation and induces cell cycle arrest and apoptosis in breast cancer (Evans et al., 2005; Bowker et al., 2006). Other nonsteroidal anti-inflammatory drugs (NSAIDs) such as sodium salicylate are utilized as agents for the treat- ment of inflammation (Weissmann, 1991). Especially, sodium salicylate is known to induce apoptosis and arrest cell cycle in a variety of cancer cells (Bellosillo et al., 1998; Klampfer et al., 1999; Law et al., 2000; Marra et al., 2000; Lee et al., 2003; Dikshit et al., 2006). However, the combined effects of metformin and sodium salicylate on cancer inhibition are not known. Therefore, in this study, we identified the anticancer effects of combined metformin and sodium salicylate treatment leading to apoptosis induction, cell cycle arrest, and inhibition of cell proliferation in MCF-7 human breast cancer cells.

To evaluate the combination effect of metformin and sodium salicylate on cancer cell inhibition, we first tested WST-1 cell proliferation assay using different doses of metformin or sodium salicylate. MCF-7 cells were seeded into 96-well plates at 40,000 cells per well and were cultured

*Received: July 4, 2017 / Revised: July 11, 2017 / Accepted: July 11, 2017

${ }^{\dagger}$ Corresponding author: Keun-Sik Kim. Department of Biomedical Laboratory Science, Konyang University, Daejeon 35365, Korea. Tel: +82-42-600-6373, Fax:+82-42-600-6565, e-mail: kskim11@konyang.ac.kr

(C) The Korean Society for Biomedical Laboratory Sciences. All rights reserved.

(9This is an Open Access article distributed under the terms of the Creative Commons Attribution Non-Commercial License (http://creativecommons.org/licenses/by-nc/3.0/) which permits unrestricted non-commercial use, distribution, and reproduction in any medium, provided the original work is properly cited. 
in EMEM (ATCC, Manassas, VA, USA) for $24 \mathrm{~h}$. After treatment with $\mathrm{IC}_{50}$ values of metformin or/and sodium salicylate for $48 \mathrm{~h}$, the cell viability was estimated using EZCyTox reagents (Daeil Lab Service, Seoul, South Korea) at $450 \mathrm{~nm}$ by VersaMax ELISA microplate reader. We observed that the combination of metformin (Fig. $1 \mathrm{~A}, \mathrm{IC}_{50}$ value $=$ $300 \mathrm{mM}$ ) and sodium salicylate (Fig. $1 \mathrm{~B}, \mathrm{IC}_{50}$ value $=60$ $\mathrm{mM}$ ) caused a synergistic inhibition of cell viability in both MCF-7 and 293T (control; human embryonic kidney) cells (Fig. 1C). Compared with the control 293T cells, the cell viability of MCF-7 cells showed greater cytotoxicity by the combined treatment $\left[\mathrm{IC}_{50}\right.$ value $=\mathrm{IC}_{25}$ of metformin $(150$ $\mathrm{mM})+\mathrm{IC}_{25}$ of sodium salicylate $\left.(30 \mathrm{mM})\right]$.

To verify the combination therapeutic effect of metformin and sodium salicylate, MCF-7 and 293T cells were treated with the drugs individually or in combination and assayed by Annexin V-FITC/PI staining (Kim and Lee, 2016). MCF-7 and $293 \mathrm{~T}$ cells were seeded into 6 -well plates $\left(5 \times 10^{5}\right.$ cells/well) and treated with $\mathrm{IC}_{50}$ values of metformin, sodium salicylate and combination of these drugs for $48 \mathrm{~h}$. Cells were washed in DPBS and resuspended in $100 \mu \mathrm{L} 1 \mathrm{X}$ Annexin-binding buffer at $10^{6}$ cells $/ \mathrm{mL}$. Cells were incubated with Annexin V Alexa Fluor 488 for 20 min at room temperature in the dark. After centrifugation, the supernatant was removed and cells were resuspended in $100 \mu \mathrm{L}$ Annexin binding buffer. Finally, cells were incubated with PI for 5 min in the absence of light and then stained cells were analyzed by a NovoCyte Flow Cytometer (ACEA Biosciences Inc, San Diego, CA, USA). In MCF-7 cells, metformin or sodium salicylate treatment induced early apoptosis by
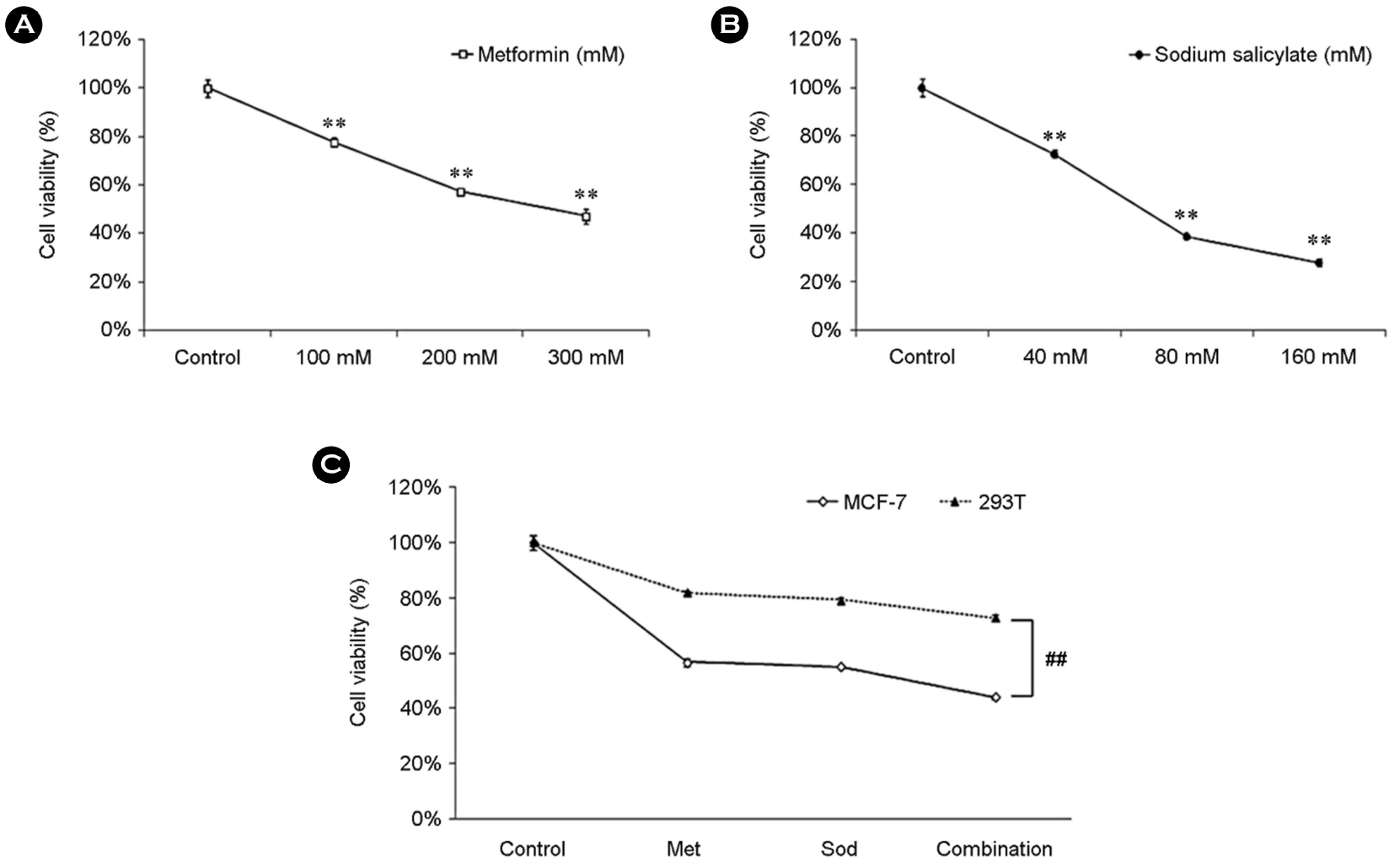

Fig. 1. Combined treatment of metformin and sodium salicylate synergistically inhibited the viability of cancer cells. Cells were exposed to the indicated concentrations of (A) metformin $(100,200$ and $300 \mathrm{mM})$ and (B) sodium salicylate $(40,80$ and $160 \mathrm{mM})$ in MCF-7 cells for $48 \mathrm{~h}$. (C) MCF-7 and 293T cells were then treated with metformin, sodium salicylate and their combinations $\left(\mathrm{IC}_{25}\right.$ of metformin $(150 \mathrm{mM})+\mathrm{IC}_{25}$ of sodium salicylate $\left.(30 \mathrm{mM})\right)$ for $48 \mathrm{~h}$. Cell viability was each monitored by WST assay. Data are represented as the mean \pm standard deviation $(\mathrm{n}=3) .{ }^{* *} P<0.01$ compared to various concentrations treated with control. \#\# $<0.01$ compared to 293T cells with MCF-7 cells. 
(A)


B
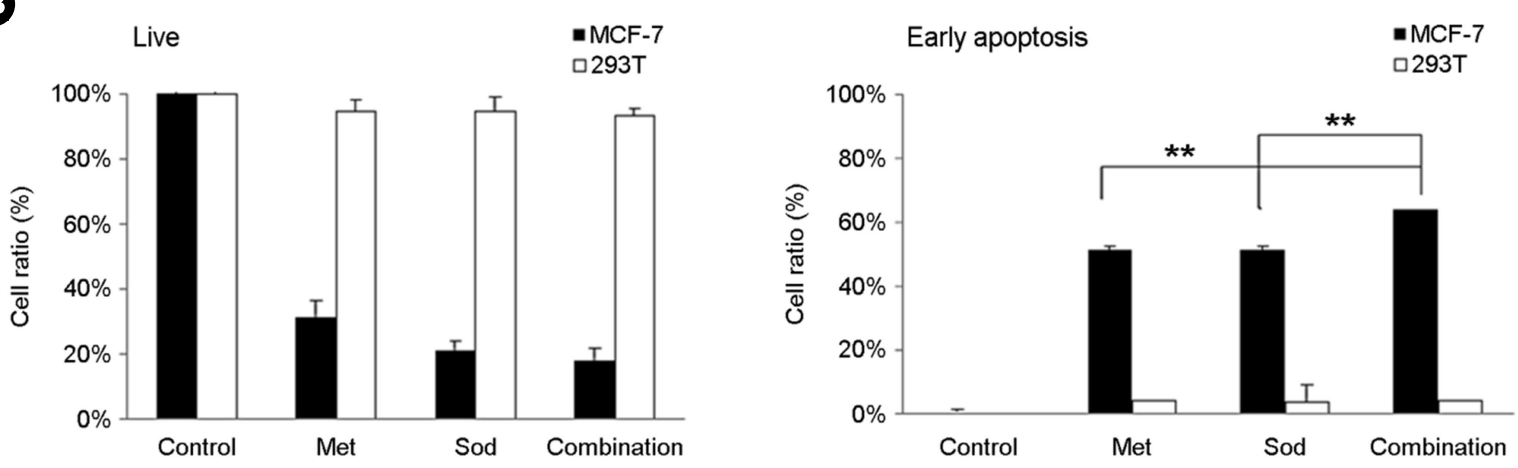

Fig. 2. Combination treatment of metformin and sodium salicylate greatly induced apoptosis in MCF-7 cells. MCF-7 and 293T cells were treated with $\mathrm{IC}_{50}$ values of metformin or sodium salicylate, respectively and combined metformin and sodium salicylate for $48 \mathrm{~h}$. Apoptosis was determined by Annexin-V/PI staining and measured by cell cytometer. The mean was calculated from three different measurements. (A) Representative flow cytometry scatter plots of propidium iodide (PI) (Y axis) vs Annexin-fluorescein isothiocyanate (FITC) (X axis). (B) Bar charts showed average quantitative data of three independent flow cytometry experiments for early apopotosis in MCF-7 and 293 T cells. $* * P<0.01$ compared metformin or sodium salicylate, respectively with combination in early apoptosis.

\section{$51.98 \%$ and $51.94 \%$, respectively. Combination of metformin} and sodium salicylate induced early apoptosis by $70.12 \%$. However, 293T cells did not undergo apoptosis induction by metformin and sodium salicylate (Fig. 2A and B). The results suggest that the pro-apoptotic ability of combination treatment was more pronounced than that of each treatment alone.

To elucidate the mechanism of inhibition of MCF-7 cell growth by a function of cell cycle arrest of metformin and sodium salicylate, cell cycle arrest was analyzed in the treated
MCF-7 cells by Tali ${ }^{\mathrm{TM}}$ Image-based Cytometer (Invitrogen, Carlsbad, CA, USA). MCF-7 cells were treated with $\mathrm{IC}_{50}$ values of metformin, sodium salicylate and combination of metformin and sodium salicylate for $48 \mathrm{~h}$. After washing with DPBS, the harvested cells were fixed with ice-cold $70 \%$ ethanol in distilled water at $10^{6}$ cells/well and kept at $20^{\circ} \mathrm{C}$ overnight. After centrifugation, the supernatant was removed and cells were resuspended in $200 \mu \mathrm{L}$ Tali $^{\circledR}$ cell cycle solution (Invitrogen, Carlsbad, CA, USA). Finally, these cells were incubated at room temperature for $30 \mathrm{~min}$ in dark and then 
(A)

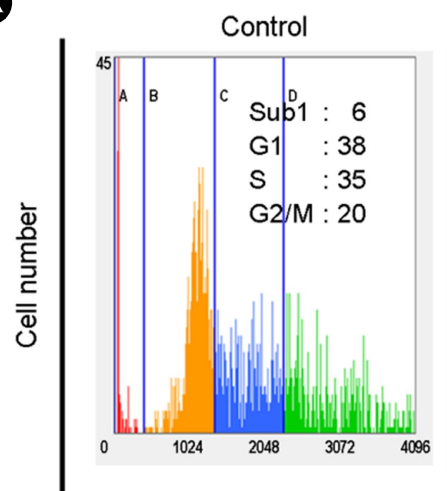

Met

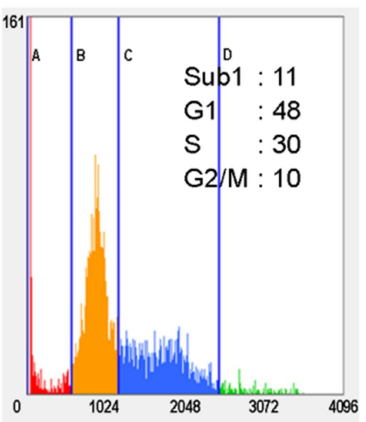



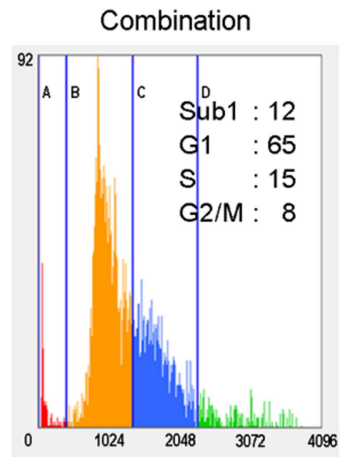

DNA content

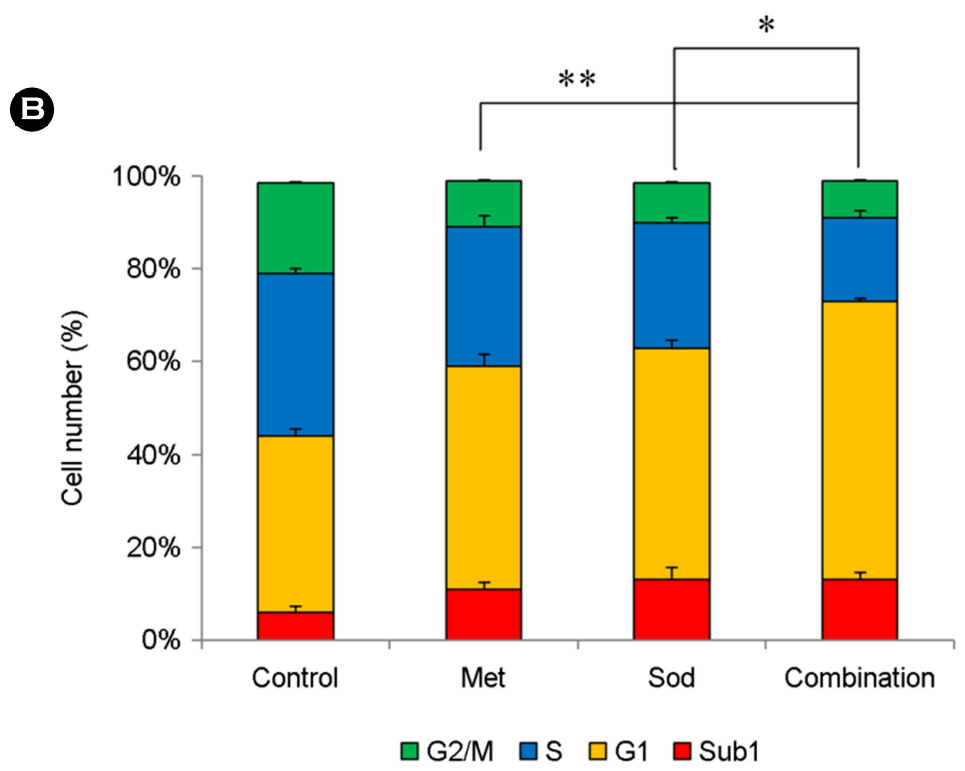

Fig. 3. Dual drugs of metformin and sodium salicylate effectively induced G1 phase cell cycle arrest in MCF-7 cells. (A) Representative histograms depicting cell cycle distribution of MCF-7 cells treated with $\mathrm{IC}_{50}$ values of metformin or sodium salicylate, respectively and combined metformin and sodium salicylate for $48 \mathrm{~h}$. (B) The cell cycle distributions were presented as cumulative proportions of cells within each of four cell cycle compartments (Sub1, G1, S and G2/M); Data were presented as means \pm SD of three independent experiments. $* P<0.05,{ }^{* *} P<0.01$ compared to metformin or sodium salicylate, respectively with combination in G1 phase. stained cells were analyzed by Tali ${ }^{\circledR}$ image-based cytometry. We observed that the combined treatment of metformin and sodium salicylate further increased the population of cells in the G0/G1 phase than treatments with either metformin or sodium salicylate alone (Fig. 3A and B).

The in vitro findings of our study demonstrated that combination treatment of metformin and sodium salicylate synergistically increased synergistic cytotoxicity in MCF-7 breast cancer cells and inhibited the proliferation of cancer cells by inducing apoptotic cell death and G0/G1 phase arrest. These studies, together with our study, collectively suggest that the combined effect by dual chemotherapeutic drugs on cancer cells is a universal phenomenon and hold a promise for future cancer treatments. However, many of the therapeutic compounds such as metformin and sodium salicylate have the disadvantage of short circulation half-life, poor solubility and instability in vivo (Hu et al., 2012). To overcome these obstacles and improve therapeutic efficiency in vivo, further studies are required to develop nanocarrier systems using liposomes to enhance drug loading capacity, increased solubility, and minimized toxic effect to normal cells.

\section{ACKNOWLEDGEMENTS}

This research was supported by Basic Science Research Program through the National Research Foundation of 
Korea (NRF) funded by the Ministry of Education (NRF2015R1D1A1A01058717).

\section{CONFLICT OF INTEREST}

The authors have no conflict of interest to declare.

\section{REFERENCES}

Aapro MS. Adjuvant therapy of primary breast cancer: a review of key findings from the 7th international conference, St. Gallen, February 2001. Oncologist. 2001. 6: 376-385.

Bellosillo B, Pique M, Barragan M, Castano E, Villamor N, Colomer

D, Montserrat E, Pons G, Gil J. Aspirin and salicylate induce apoptosis and activation of caspases in B-cell chronic lymphocytic leukemia cells. Blood. 1998. 92: 1406-1414.

Bowker SL, Majumdar SR, Veugelers P, Johnson JA. Increased cancer-related mortality for patients with type 2 diabetes who use sulfonylureas or insulin. Diabetes Care. 2006. 29: 254-258.

Conforti F, Menichini F. Phenolic compounds from plants as nitric oxide production inhibitors. Current Medicinal Chemistry. 2011. 18: 1137-1145.

Dikshit P, Chatterjee M, Goswami A, Mishra A, Jana NR. Aspirin induces apoptosis through the inhibition of proteasome function. Journal of Biological Chemistry. 2006. 281: 29228 $-29235$

Evans JM, Donnelly LA, EmslieSmith AM, Alessi DR, Morris AD. Metformin and reduced risk of cancer in diabetic patients. British Medical Journal. 2005. 330: 1304-1305.

Hu K, Law JH, Fotovati A, Dunn SE. Small interfering RNA library screen identified polo-like kinase-1 (PLK1) as a potential therapeutic target for breast cancer that uniquely eliminates tumor-initiating cells. Breast Cancer Research. 2012. 14: R22.

Hu LX, Du YY, Zhang Y, Pan YY. Synergistic effects of exemestane and aspirin on MCF-7 human breast cancer cells. Asian Pacific Journal of Cancer Prevention. 2012. 13: 5903-5908.

Kim IS, Lee JS. Association of anti-apoptotic mechanism due to house dust mite in neutrophils with protein synthesis and bad. Biomedical Science Letters. 2016. 22: 211-214.

Klampfer L, Cammenga J, Wisniewski HG, Nimer SD. Sodium salicylate activates caspases and induces apoptosis of myeloid leukemia cell lines. Blood. 1999. 93: 2386-2394.

Law BK, WaltnerLaw ME, Entingh AJ, Chytil A, Aakre ME, Norgaard P, Moses HL. Salicylate-induced growth arrest is associated with inhibition of $\mathrm{p} 70 \mathrm{~s} 6 \mathrm{k}$ and down-regulation of c-myc, cyclin D1, cyclin A, and proliferating cell nuclear antigen. Journal of Biological Chemistry. 2000. 275: 38261 $-38267$.

Lee EJ, Park HG, Kang HS. Sodium salicylate induces apoptosis in HCT116 colorectal cancer cells through activation of p38MAPK. International Journal of Oncology. 2003. 23: 503 -508 .

Mandy ML, Ying H, Jeffrey W. Developing phytoestrogens for breast cancer prevention. Anti-Cancer Agents in Medicinal Chemistry. 2012. 12: 1306-1313.

Marra DE, Simoncini T, Liao JK. Inhibition of vascular smooth muscle cell proliferation by sodium salicylate mediated by upregulation of p21(Wafl) and p27(Kip1). Circulation. 2000. 102: 2124-2130.

Weissmann G. Aspirin. Scientific American. 1991. 264: 84-90.

https://doi.org/10.15616/BSL.2017.23.3.290

Cite this article as: Kim YJ, Park HB, Kim PH, Park JS, Kim KS. Enhanced Anti-cancer Efficacy in MCF-7 Breast Cancer Cells by Combined Drugs of Metformin and Sodium Salicylate. Biomedical Science Letters. 2017. 23: $290-294$ 